Article

\title{
Autochthonous Micrite to Aphanodolomite: The Microbialites in the Dolomitization Processes
}

\author{
Adriano Guido *, Franco Russo, Domenico Miriello and Adelaide Mastandrea \\ Department of Biology, Ecology and Earth Sciences, University of Calabria, Via Bucci, Cubo 15B, I-87036 Rende, \\ Cosenza, Italy; francorusso44@gmail.com (F.R.); miriello@unical.it (D.M.); a.mast@unical.it (A.M.) \\ * Correspondence: aguido@unical.it; Tel.: +39-328-8429290
}

Received: 31 October 2018; Accepted: 30 November 2018; Published: 3 December 2018

updates

\begin{abstract}
In the present paper, we examine the influence of micrite types, autochthonous or allochthonous, on the dolomitization processes. The recrystallized and dolomitized Carnian samples from Rifugio Vallandro and Alpe di Specie erratic boulders (South Tyrol, Italy) offer a unique example for studying the relationship between microbialites and dolomitization processes. The comparison between the carbonates of the well-preserved erratic boulders of Alpe di Specie and the isochronous, recrystallized, and dolomitized, samples of Rifugio Vallandro, allows for hypothesizing the role of microbialites on dolomitization processes. The Rifugio Vallandro samples represent variously dolomitized boundstone (made of corals, sponges, and peloidal crusts) with a fine texture (aphanodolomite) which contain organic matter relics, suggesting microbial-mediated mineralization. Geomicrobiological characterization of the microbialites from Alpe di Specie indicates that they formed through microbial metabolic activity of sulfate-reducing bacteria, which thrive on organic matter accumulated in the suboxic to anoxic interspaces of the skeletal framework. Similar processes can be hypothesized for the microbialite precursor of Rifugio Vallandro. Extracellular polymeric substance (EPS) and other organic compounds trapped inside the fine crystal matrix can have a role in the dolomitization processes of the microbialites. High $\mathrm{pH}$ and high alkalinity, derived from the degradation of organic matter, may be critical in promoting the dolomitization of microbialites because the high $\mathrm{pH}$ increases the concentration and activity of the dissolved $\mathrm{CO}_{3}{ }^{2-}$, thereby increasing the dolomite supersaturation and reaction rates. This process produces very fine dolomite (aphanodolomite) that replaces the original organic-rich micrite, while the fine crystalline dolomite forming larger euhedral crystals seems to derive from the allochthonous micrite due to the presence of a large amount of siliciclastics and the absence of organic remains.
\end{abstract}

Keywords: microbialites; organic matter; bacteria; dolomitization; Carnian; dolomite; Italy

\section{Introduction}

Dolomite forms in many different surface and burial environments. It is a highly variable mineral whose molecular structure, stoichiometry and trace element composition indicate different conditions of formation. These variables do preclude seeking a common dolomitization model. In fact, the physico-chemical factors determining crystal nucleation and growth are not completely understood. Dolomite can mineralize in seawater, mixed or burial environments and the fact that dolomite is associated with normal seawater, brine, or meteoric water (all being possible) is not absolute proof of cause and effect. Based on the formation mode, dolomite is divided into two groups: primary and secondary [1]. The primary dolomite precipitates directly from an aqueous solution through microbial activities, the secondary dolomite is a diagenetic product formed from a carbonate precursor (calcite or aragonite) through a dolomitization process. 
In recent decades, laboratory experiments, using anaerobic bacterial culture, provided evidence to understand the mechanisms that may be involved in the primary dolomite precipitation under Earth surface conditions [2,3]. The microbial model of dolomite precipitation [4] states that dolomite can precipitate during bacterial sulfate reduction (BSR), which supplies $\mathrm{HCO}^{3-}$ ions and consumes $\mathrm{SO}_{4}{ }^{2-}$ and seems to be an inhibitor of dolomite growth [5]. Methanogenesis and aerobic halophilic heterotrophic bacteria are other types of metabolic activity involved in dolomite precipitation $[5,6]$. These studies demonstrated the importance of microbial processes in carbonate mineral formation with the presence of the active cells and associated biofilms being an essential ingredient [7]. The identification of bacterial traces in recent and ancient microbial dolomites has led to the proposal of the same microbiological processes for older dolomites [8-12]. Organodiagenesis, which is related to the role of bacterial sulfate reduction and methanogenesis in overcoming barriers to dolomite nucleation within anoxic, organic-rich sediments at earth surface temperature, has also been discussed $[13,14]$.

Most evaluations of secondary dolomitization have dealt with supplying magnesium to the system while the precursor carbonate type was not sufficiently considered. Numerous depositional and geochemical models were developed to interpret the variety of secondary dolomite in the rock record [14-21]. Generally, dolomites were formed by replacement of the meta-stable calcium carbonates, such as aragonite and high-Mg calcite. Seawater is the ideal source for dolomitizing solutions because of its high concentration of magnesium ions [7]. The widely accepted hypothesis of dolomitization is that limestone, through partial replacement of $\mathrm{Ca}$ with $\mathrm{Mg}$ ions, transforms into dolomite [22-27]. During dolomitization, the dissolution of the precursor mineral calcite supply the much-needed $\mathrm{Ca}^{+2}$, and the dolomitizing fluids carry $\mathrm{Mg}^{+2}$ and $\mathrm{CO}_{3}{ }^{-2}[1,28]$. Dolomite formation seems to be favored by: (a) an efficient and long-lasting supply of aqueous solution with a high $\mathrm{Mg}^{+2} / \mathrm{Ca}^{+2}$ ratio and carbonate alkalinity; (b) an elevated temperature [25]; and (c) a high degree of supersaturation [29]. Conceptual models, such as the storm recharge-evaporative pumping, Sakha model of [30], or the reflux model of [31], explain the pervasive dolomitization of carbonate bodies.

The Triassic platforms of Northern Italy represent well-known cases of complete dolomitization [32]. The pathway that led to the dolomitization of these platforms involved different steps from the surface to burial diagenetic environments, identified through the microfacies, microstructural characteristics, and geochemical data of dolomite [33-35]. Here, we discuss the influence of the micrite type, autochthonous (microbialites) or allochthonous (detrital micrite), on secondary dolomitization processes. The recrystallized and dolomitized Carnian samples from Rifugio Vallandro and the well-preserved isochronous erratic boulders of Alpe di Specie (South Tyrol, Italy) offer a unique case study for investigating the relationship between microbialites and dolomitization processes [36].

\section{Geological Background}

The carbonate platforms of the Dolomites, from the Anisian through to the Carnian stage, record the evolution from low-relief terrigenous carbonate ramps rich in loose micritic mud to isolated high-relief carbonate pinnacles dominated by autochthonous micrite and syndepositional cements and back to low-relief mixed ramps [36-39].

In the Eastern Dolomites, the Middle Carnian registers the demise of the high-relief rimmed platforms and the accumulation of shallow-water loose sediments which are terrigenous-carbonate in nature and are often enriched in terrestrial plant remains [38]. The Heiligkreuz Fm., according to the definition of Keim et al. [40] and Stefani et al. [37], corresponds to the Dürrenstein Fm. of Pisa et al. [41] and Bosellini [42], and corresponds to the Dürrenstein Fm. sensu De Zanche et al. [43] and subsequent works [44-46]. This unit records a succession of rather complex depositional events, in which the climatic variations probably play a significant role, with an alternation of humid with semi-arid climate episodes. The Heiligkreuz Fm. overlaps in concordance with the Formation of San Cassiano and is onlap with the slopes of the Cassian platforms.

The lower part of the Heiligkreuz Formation was deposited in a subtidal, shallow, marine setting, as documented by the sedimentary structures including hummocky cross-lamination, while the upper 
part is characterized by the repeated stacking of meter-size peritidal cycles capped by subaerial exposure surfaces marked by teepee and paleosoils [36]. The deposition of the Heiligkreuz Formation is initiated by the combined effect of the sedimentary shallowing of the San Cassiano basins due to the progressive infilling by platform-derived sediments and extrabasinal terrigenous muds and a significant sea level drop [42]. In some localities (i.e., Forcella Giau, Rifugio Di Bona), at the bottom of the formation, a shallow water unit consisting of an admixture of carbonate and terrigenous shaly to sandy sediments prevented the carbonate fraction from a complete dolomitization. Here, skeletons show a unique preservation state with their aragonite mineralogy in a pristine state $[36,47,48]$. Biostromes, showing "modern Mesozoic" features, with diversified colonial corals, stromatoporoids, and sponges are present in the basal portion of the Heiligkreuz Formation.

During the Carnian stage, a primary skeletal framework developed for the first time [36]. However, the coral-rich biostromes were short-lived, since low-angle terrigenous carbonate ramps soon developed, rich in loose micritic muds, bioclastic material, and ooids. During the following Late Triassic period, terrigenous input stopped, and regional low-relief peritidal successions (Dolomia Principale) accumulated to a great thickness [42,49].

\section{Study Area}

The Alpe di Specie area is located at the western end of the slope of the Cassian platform of the Picco di Vallandro Mountain, see Figure 1. In the Prato Piazza-Alpe di Specie area, on the west of the slope, the Heiligkreuz Dolomite directly overlies the San Cassiano Fm. The geometrical relationships between Cassian Dolomite, S. Cassiano Fm., and Heiligkreuz Dolomite are strongly disturbed by tectonics [36]. The Carnian fauna, present in this interval, is one of the most important in the world [36,50-56]. Although, the exact stratigraphic position of the deposits is hindered by poor exposure. Generally, they have been regarded as small patch reefs that are either in situ [51] or out of place [36,54,57], see Figure 2. Most of the research was carried out on erratic boulders embedded in peaty soil in the meadows of the Alpe di Specie, where they are distributed along a continuous belt above the deep-water of the San Cassiano Fm. and below the shallow water of the Heiligkreuz Dolomite. Wide, unexposed zones and strong tectonics make it difficult to determine their stratigraphic setting [36].

A bioclastic limestone horizon, at the bottom of the typical Heiligkreuz Dolomite (Rifugio Vallandro section), contains at least three frame-builder horizons, with corals, sponges, and stromatoporoids in life position, see Figure 3. Although this unit is strongly recrystallized and dolomitized, its faunal content and facies patterns show strong affinities with those of the very well preserved erratic boulders and it allows for comparison of the two carbonate bodies from geochemical and geomicrobiological points of view. 


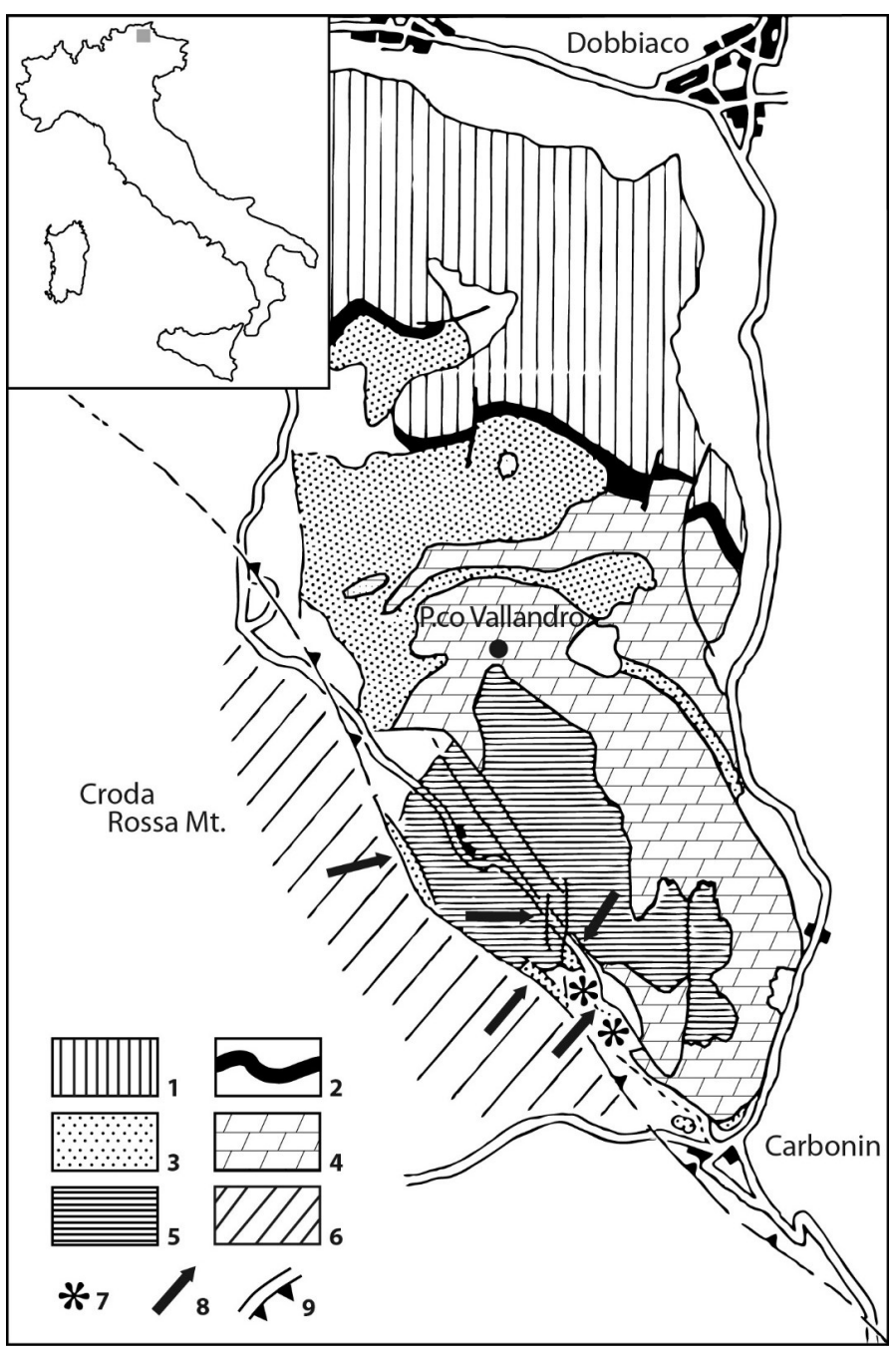

Figure 1. Schematic geologic map of the Picco di Vallandro (Heiligkreuz) Mountain (1) pre-Ladinian formations; (2) Livinallongo (Buchenstein) Formation; (3) Wengen and San Cassiano formations; (4) Schlern (Ladinian) and Cassian (Carnian) platforms; (5) Heiligkreuz Dolomite and Raibl beds; (6) Dolomia Principale; (7) position of the main erratic boulder swarms in Alpe di Specie (Seelandalpe) area; (8) position of studied outcrops; (9) faults and overthrusts (modified from [36]).

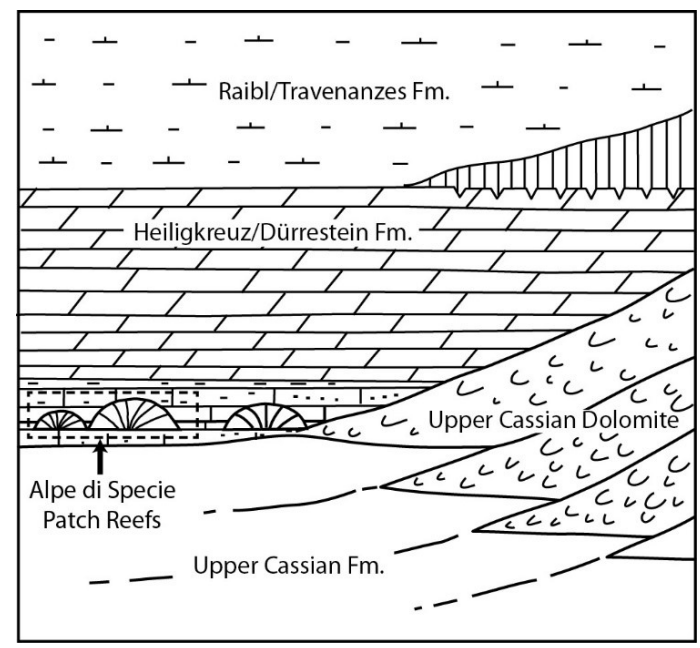

Figure 2. Simplified scheme showing the stratigraphic setting of Alpe di Specie patch reefs (modified from Russo et al., 1991). 


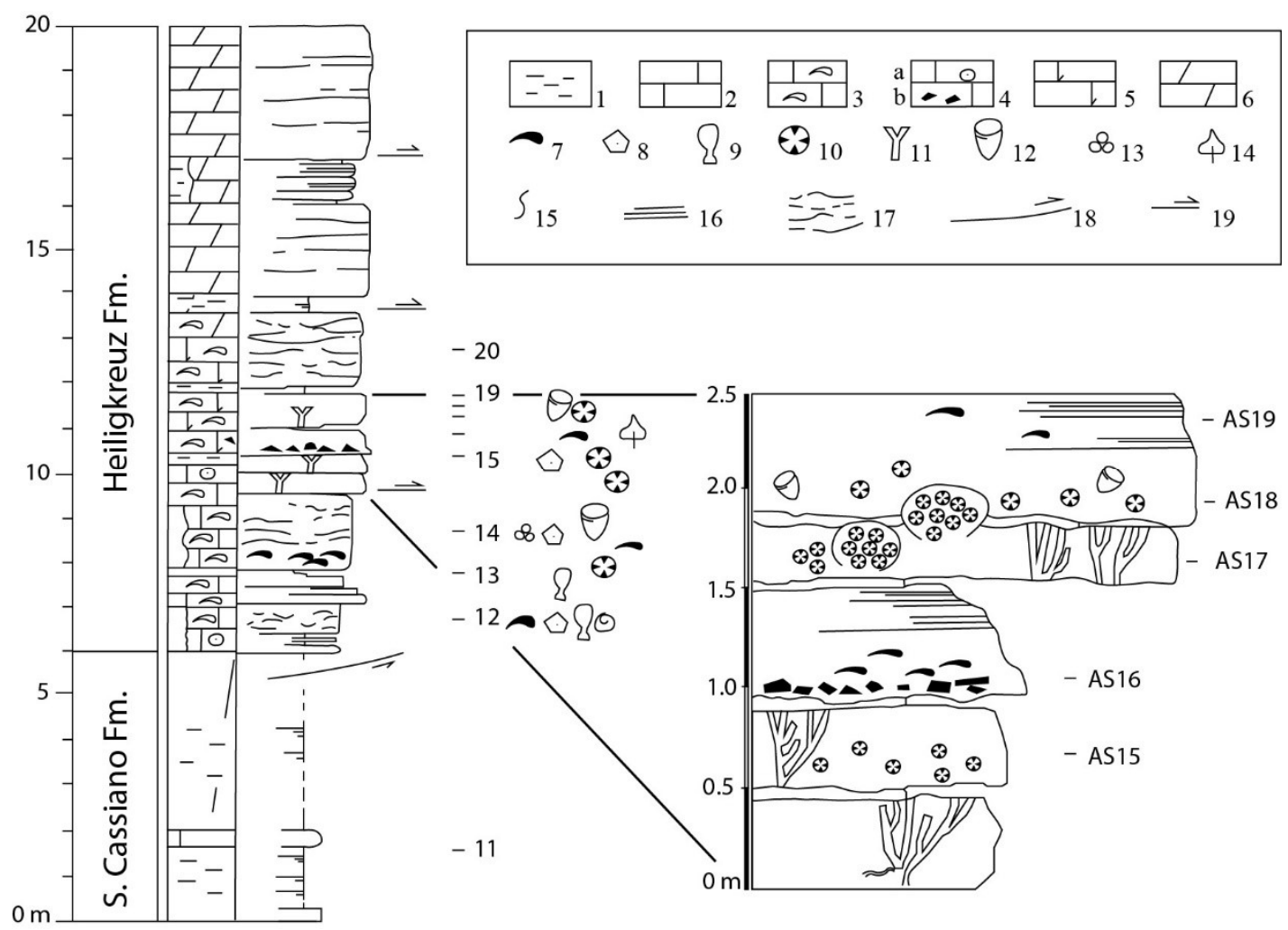

Figure 3. Stratigraphic section at the boundary between San Cassiano Fm and Heiligkreuz Fm on the road that cuts near Rifugio Vallandro with the location of the studied samples (modified from [36]).

\section{The Rifugio Vallandro Section and the Alpe di Specie Erratic Boulders}

The Rifugio Vallandro section and the erratic boulders from the meadows of the Alpe di Specie were studied by Russo et al. [36] in order: (a) to reconstruct the stratigraphic sequence at the S. Cassiano/Heiligkreuz boundary, and (b) to understand the different diagenetic histories of the dolomitized frame-builder horizons of Rifugio Vallandro and the well-preserved erratic boulders.

The Rifugio Vallandro section comprises the S. Cassiano-Heiligkreuz boundary, see Figure 3. The section is bounded by faults at the base and at the top. The S. Cassiano Formation is composed by badly exposed to unexposed grey marls with decimeter thick intercalations of marly mudstone and fine-grained peloidal to bioclastic packstone and wackestone. Russo et al. [36] recognized three main lithofacies in the Heiligkreuz Formation, see Figure 4: (1) bioturbated nodular carbonates with irregular marly lenses and drapes, frequently coating the calcareous nodules. (2) calcarenite storm-layers composed of thick bioclastic (bivalves, echinoderm remains, and coral fragments), intraclastic/peloidal storm-layers, with erosional bases, normal grading, and basal lags, even to low angle lamination. (3) frame-builder beds constituted by more or less dolomitized boundstone, with corals, sponges, chaetetids, and stromatoporoids in life position. Three horizons of frame-builders were recognized. Fine pelitic sediments which are alternated to the frame builder horizons are probably responsible for the temporary interruptions of colony growth.

The dolomitization does not allow recognition of the full taxonomic diversity, see Figure 4 . The massive forms, occurring as molds filled up by late calcite spar, are still recognizable. Russo et al. [36] were able to correlate these beds with erratic boulders for the paleontological content and depositional/stratigraphic features.

Erratic boulders, shown in Figure 5, are dispersed in the Alpe di Specie meadow inside the basinal sediments of the S. Cassian Fm. Considering the gravity displacement of the blocks, it is difficult to define their stratigraphic position, even if it is presumable that they derive from similar carbonate facies of the Heiligkreuz Fm. 


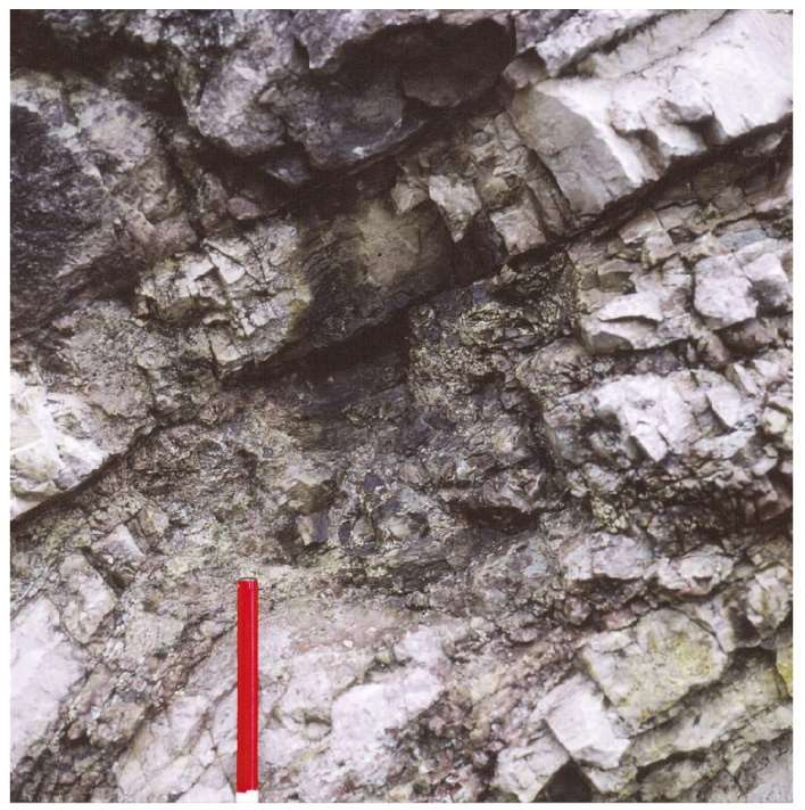

Figure 4. Recrystallized and dolomitized strata of the Rifugio Vallandro section.

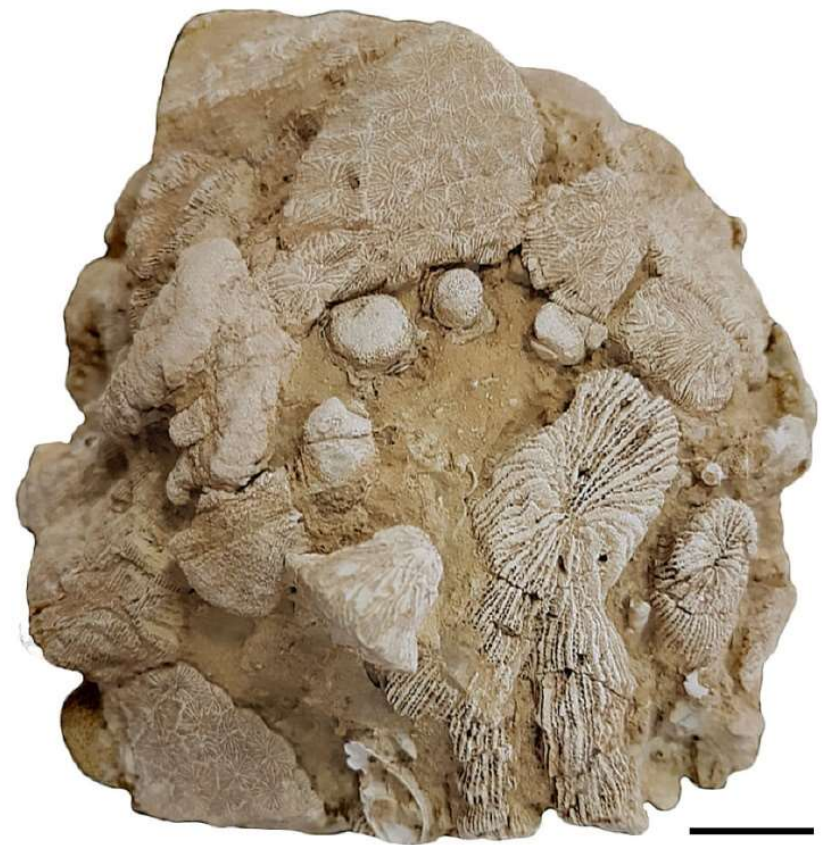

Figure 5. A typical "erratic boulder" from Alpe di Specie, dominated by colonial corals and demosponges.

Several authors supplied the paleontological and taxonomic features of the frame-builders and reef-dwellers from Alpe di Specie $[36,53,54,57,58]$. The assemblage is composed of frame-building organisms dominated by few taxa (mainly sponges and corals), associated with subordinate encrusting and dwelling fauna [36].

Here, we have investigated the micrite component of both the carbonate bodies to establish possible correlations between the micrite type (autochthonous or allochthonous) and the dolomitization processes.

\section{Sample Preparation and Methods}

We investigate the same samples of the Rifugio Vallandro section analyzed by Russo et al. [36], see Figure 3. The samples were cut into small blocks $(5 \times 3 \times 1 \mathrm{~cm})$. They were then subdivided into two parts and, considering the two corresponding cutting surfaces, one part was utilized 
to obtain a polished slab and the other a thin section. In this way, it was possible to select, on the polished slab, the areas with high epifluorescence and verify, in the opposite thin section, the corresponding microfacies. Detrital and autochthonous micrite have been distinguished and analyzed using Raman Spectroscopy.

Uncovered thin sections $(48 \mathrm{~mm} \times 28 \mathrm{~mm})$ and polished slabs were studied with an optical microscope (Zeiss Axioplan II), under plane and cross-polarized light, at a magnification of 2.5, $5,10,20$, and $40 \times$. The samples were examined for fluorescence to reveal the distribution of the organic matter (OM). Fluorescence was induced by a Hg vapor lamp linked to an Axioplan II imaging microscope (Zeiss) equipped with high-performance wide-band pass filters (BP 436/10 nm/LP $470 \mathrm{~nm}$ for green light; BP 450-490 nm/LP $520 \mathrm{~nm}$ for yellow light).

For Scanning Electron Microscope (SEM) observations and Electron Probe Micro Analyzer (EMPA) analyses, the samples were polished with 0.25 microns diamond-impregnated surfaces, then gently etched $(0.05 \% \mathrm{HCl}, 1 \mathrm{~min})$ and carbon- or gold-coated (ca. $250 \AA$ coating thickness), respectively, depending on whether they were prepared for microanalysis (EMPA) or morphological study (SEM). SEM observations were carried out on polished thin-sections and freshly broken surfaces to detect the micro- and nano-morphology of the main carbonate constituents, using a FEI-Philips ESEM-FEG Quanta 200F, operating with a voltage of $15 \mathrm{kV}$ and a working distance of between 10 and $15 \mathrm{~mm}$. Mineralogical and chemical composition was detected using an Electron Probe Micro Analyzer-JEOL-JXA 8230. EMPA working conditions were as follows: voltage, $15 \mathrm{keV}$; probe current, $10 \mathrm{nA}$; working distance, $11 \mathrm{~mm}$; take-off angle, $40^{\circ}$; live time, $50 \mathrm{~s}$.

Micro-Raman analyses were performed using a Thermo Fisher DXR Raman microscope (Waltham, MA, USA), equipped with OMNICxi Raman Imaging software 1.0, an objective of $50 \times$, a grating of $900 \mathrm{ln} / \mathrm{mm}$ (full width at half maximum, FWHM), and an electron multiplying charge-coupled device (EMCCD). The 532-nm line (solid state laser) was used at an incident power output ranging from 1.8 to $7 \mathrm{~mW}$. The spatial resolution of the laser beam was approximately $3-5 \mu \mathrm{m}$. The acquisition time of the spectra varied from 5 to $40 \mathrm{~s}$. Data were collected in the $50-3360 \mathrm{~cm}^{-1}$ range to capture the first- and second-order Raman bands. The measurements were collected on randomly oriented grains, with a fixed orientation of the polarized laser beam.

Even if the occurrence of high-intensity fluorescence complicates the identification of individual Raman-active vibrational modes, by hiding the corresponding Raman bands, we were able to identify the main carbonaceous material peaks within the microbialite mineral phases.

\section{Results}

\subsection{Carbonate Components of Erratic Boulders}

Alpe di Specie coralgal patch reefs consist mainly of scleractinian corals, sponges, and calcareous red algae, see Figure 6a-c. Different textures are recorded in the erratic boulders derived from the patch reefs, ranging from wackstone to boundstone facies. These bioconstructions are rich in cavities, representing $35 \%$ of the overall volume. Early cements are scarce. Two micrite types have been recognized: allochthonous and autochthonous. The allochthonous micrite shows a very dense mud texture engulfing small intraclasts, peloids, and bioclasts. This fraction, rich in wackestone facies, is composed of Mg-calcite with an average Ca content of 82.0 mole \% and Mg 5.3 mole \%. A minor amount of $\mathrm{Fe}(0.7$ mole \%) and a discrete quantity of clay minerals ( $\mathrm{Si}, \mathrm{Al})$ have been detected $(8.00$ mole \%). Weak epifluorescence testifies to the absence of organic matter remains in the allochthonous fraction. The autochthonous micrite, derived from microbial activities, fill the intra- and inter-skeletal microcavities, see Figure 6a-e. This component, formed in situ, shows mainly peloidal and aphanitic (structureless) micrite. It is composed of crystals smaller than $4 \mu \mathrm{m}$. These microbial-derived fractions, composed on average of Ca 90.1 mole $\%, \mathrm{Mg} 8.3 \mathrm{~mole} \%$, and 1.6 mole $\%$ of siliciclastic minerals, displays bright fluorescence indicating a discrete amount of organic matter remains, see Figure 6f. Pyrite framboids are homogeneously distributed in autochthonous micrite. 

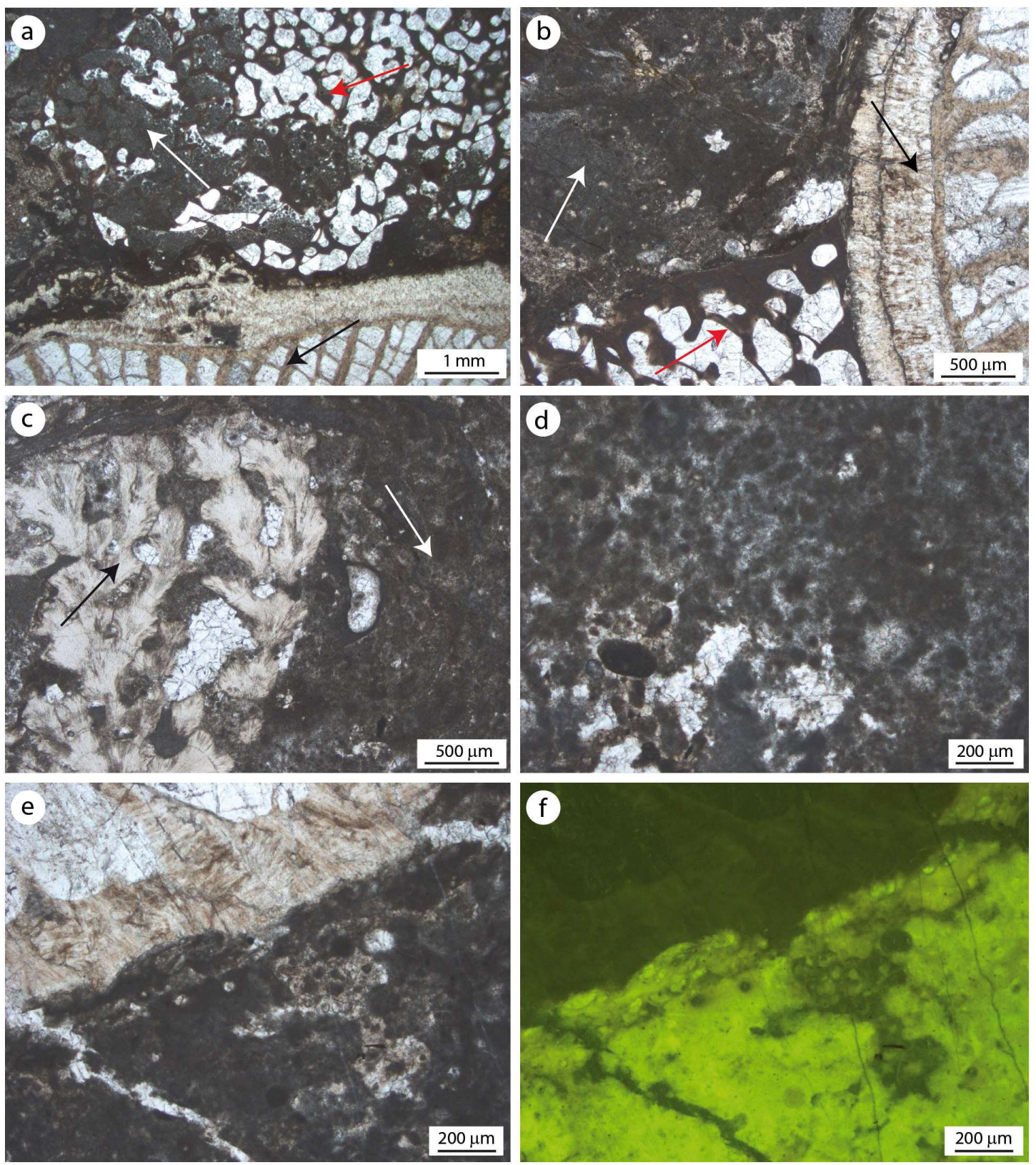

Figure 6. Main microfacies of the Alpe di Specie erratic boulders. (a,b) Boundstones made of corals (black arrows), sponges (red arrows), and autochthonous micrite filling the intra- and extra-skeletal cavities (white arrows). (c) A red alga, Dendronella articulata (black arrow), surrounded by autochthonous micrite. (d) Autochthonous micrite showing peloids or clotted peloids. (e,f) Autochthonous micrite (bottom right) and a portion of corallite wall (top left) observed in incident light (e) and Ultraviolet (UV) epifluorescence (f); the high fluorescence reveals the high organic matter content inside the microbialite.

\subsection{Carbonate Components of Rifugio Vallandro Section}

The Rifugio Vallandro section contains frame-builder intervals with corals and sponges. The dolomitization process, which proceeded evenly but patchy, shows differences according to the position of the skeletal boundstone. The boundstone facies are detectable mainly at mesoscale observations in which corals in life position are highly visible. The microfacies are often hindered by the dolomitization. Subordinately, wackestone/packestones facies are still recognizable. Frame-builder organisms are generally enveloped by a fine dolomite matrix, see Figure $7 \mathrm{a}, \mathrm{b}$, which can be divided into two components: finely-crystalline $(>20 \mu \mathrm{m})$, here named finely crystalline dolomite, 
that is attributable to the allochthonous fraction; and very finely crystalline (less than 4-5 $\mu \mathrm{m}$ ), here named aphanodolomite, without texture (aphanitic), see Figure $7 \mathrm{a}-\mathrm{c}$, or sometimes showing peloids, see Figure 7c, that corresponds to the autochthonous fraction (microbialites). The ratio between the two components is variable along the sections with the allochthonous component dominating in the wackestone/packestone and the autochthonous one prevailing in the boundstones. EPMA microanalyses and SEM observations allowed for detection of the composition and micro- and nano-morphologies of the main components. Dolomite occurs diffusely throughout the bioconstruction and replaces the original calcite/aragonite mineral phases of the skeletons and matrix, except for the coral skeletons, whose molds are filled by late anhedral blocky crystalline calcite.
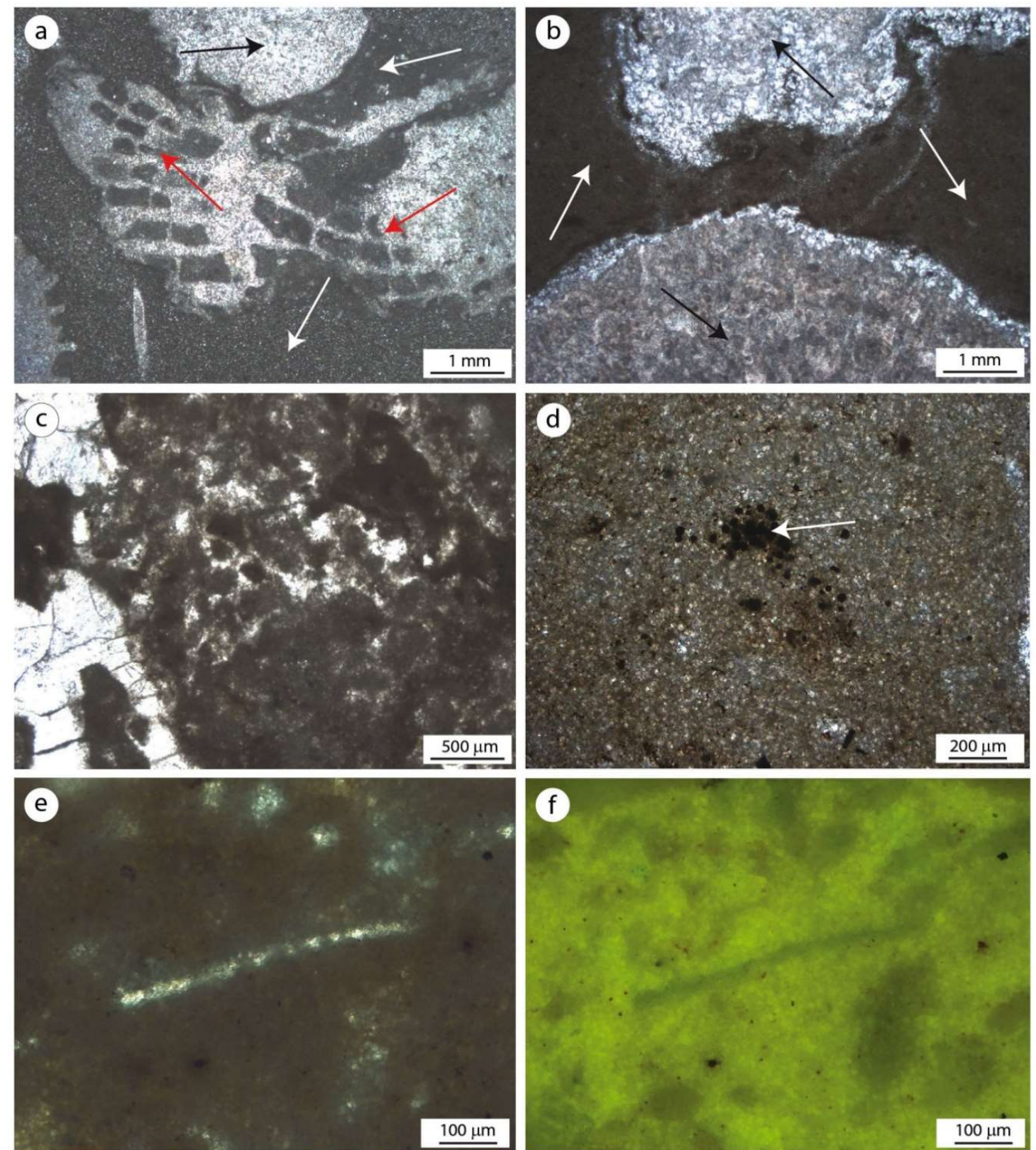

Figure 7. Rifugio Vallandro microfacies showing the autochthonous carbonate matrix affected by early organogenic dolomitization. (a,b) Aphanodolomites (white arrows) in cavities among sponges (red arrows) and corals (black arrows). (c) Aphanodolomite with dolomitized peloids. (d) Pyrite framboids (white arrow) among the aphanodolomite crystals. (e,f) Aphanodolomites observed in incident light (left) and UV epifluorescence (right); note the fluorescence is indicative of the organic matter content. 
The aphanodolomite crystals do not exceed 4-5 $4 \mathrm{~m}$. Therefore, they are about the same size as the autochthonous micrite observed in the preserved samples of the erratic boulders, see Figures 8 and 9. The aphanodolomite shows sub-euhedral to anhedral micro-crystals composed of Ca-dolomite with an average Ca content of 61.0 mole \%, 37.0 mole \% of $\mathrm{Mg}$, and $2.0 \mathrm{~mole} \%$ of siliciclastic minerals ( $\mathrm{Si}, \mathrm{Al})$. In the more recrystallized samples, the small crystals of dolomites aggrade in larger rhombic crystals, see Figure 10a. An amorphous substance, characterized by a high amount of carbon, see Figure 10c,d, and micro-spheroidal bodies are engulfed among the aphanodolomite crystals, see Figure 10c. Microsparitic cement, with an average composition of 93.7 mole \% of Ca, 5.7 mole \% of $\mathrm{Mg}$, and 0.6 mole \% of siliciclastic, is present around the Ca-dolomitic peloids. The cement filling the coral cavities is composed of sparite with an average composition of 98.2 mole \% of Ca and 1.8 mole \% of Mg. Framboidal pyrites occur as solitary spherules or irregular masses in the aphanodolomites, see Figures 7 and 10. A feeble epifluorescence linked to the remains of the organic matter is observable around these components, see Figure $7 \mathrm{~d}$.
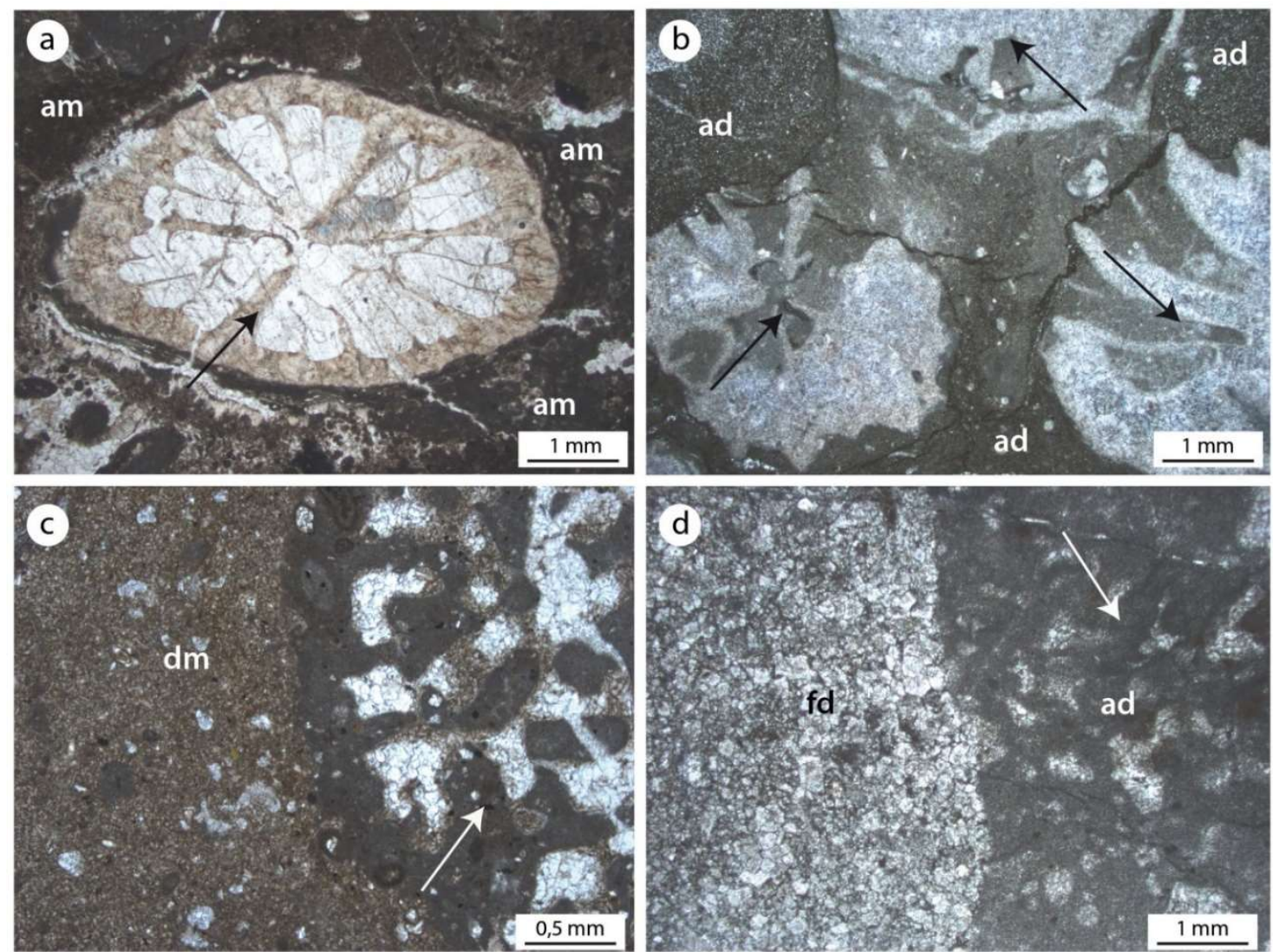

Figure 8. Comparison between the very well preserved microfacies from Alpe di Specie $(\mathbf{a}, \mathbf{c})$ and the isochronous recrystallized and dolomitized microfacies from Rifugio Vallandro (b,d). The wall and the septa of the coral in (a) are preserved in the original mineralogy (aragonite) while those in (b) are coral casts of sparry calcite. Autochthonous micrite (am) in (a) is transformed in aphanodolomite (ad) in (b). Detrital micrite $(\mathrm{dm})$ in (c) is transformed in finely-crystalline (fd) dolomites in (d). The primary micritic Mg-calcite of sponges sclerotissue (white arrow) of (c) transforms in aphanodolomite (ad) in the recrystallized samples of Rifugio Vallandro.

The finely crystalline dolomite (allochthonous) is composed of larger dolomite crystals (>20 $\mu \mathrm{m})$ in comparison to those of the aphanodolomite. It shows crystals with well-defined euhedral morphology and sizes from $20 \mu \mathrm{m}$ up to $50 \mu \mathrm{m}$, see Figure 9b. This dolomite has an average Ca content of 49.6 mole \%, 44.5 mole \% of $\mathrm{Mg}$, and 6.9 mole \% of siliciclastic and, differently from the aphanodolomite, does not show fluorescence and framboidal pyrite. 

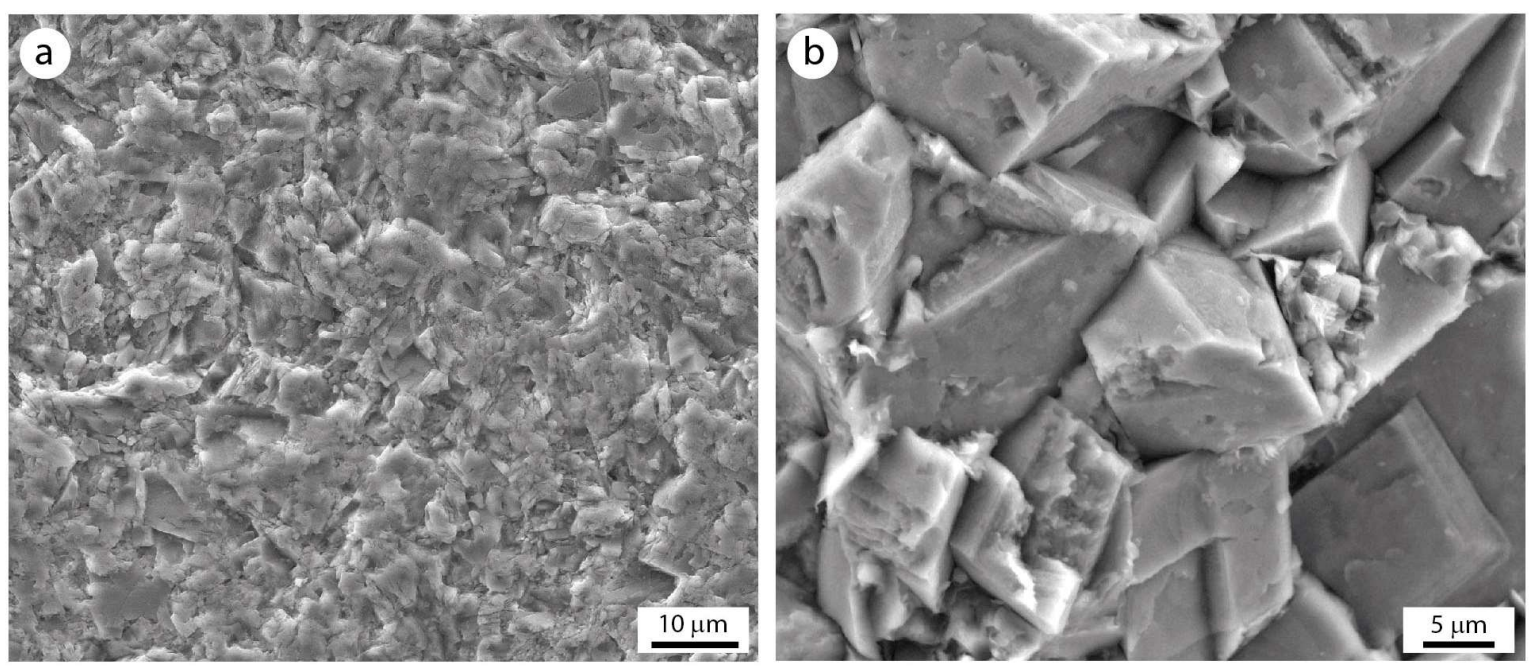

Figure 9. SEM pictures showing the crystal size and shape of the aphanodolomite (a) and finely crystalline dolomite $(\mathbf{b})$.
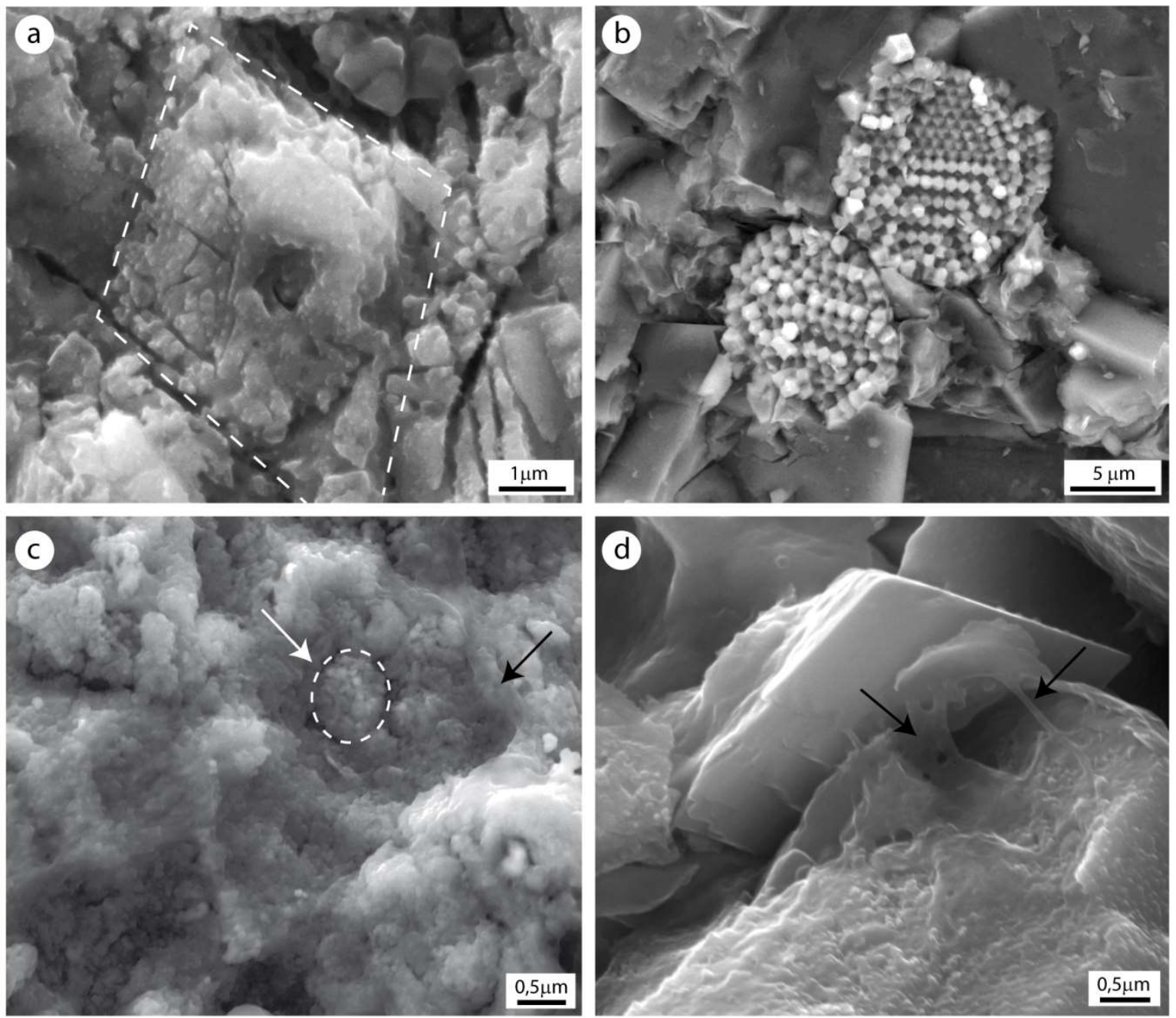

Figure 10. SEM pictures showing: (a) aphanodolomite aggrading in larger rhombic crystals (dotted line); (b) framboidal pyrite among aphanodolomite crystals; (c) aphanodolomite with sferules tentatively attributed to bacterial remains (white arrow) and mineralized Extracellular Polimeric Substances (EPS) (black arrow); (d) traces of amorphous carbonaceous material (black arrows) are attributable to EPS remains scattered among aphanodolomite crystals. 


\subsection{Carbonaceous Material Localization and Characterization with Raman Spectroscopy}

Raman spectroscopy was performed on the autochthonous and allochthonous micrite of Alpe di Specie and aphanodolomite and finely-crystalline dolomite of Rifugio Vallandro. The Raman analyses were made to confirm the presence of carbonaceous material in autochthonous micrite and its absence in allochthonous micrite, as indicated by epifluorescence observations. Indeed, the micro-Raman system is capable of analyzing the organic and inorganic features in the samples with a resolution on the micrometer scale. Differently from the XRD or GC-MS analyses, which require the extraction of carbonaceous material (CM), Raman microspectroscopy allows in situ measurements on polished slabs and thin sections. The peaks detected in the samples are located in the range between $50 \mathrm{~cm}^{-1}$ and $3360 \mathrm{~cm}^{-1}$.

The spectra on detrital and autochthonous micrite of the erratic boulder samples show the typical calcite bands. The four prominent absorption bands of the calcite were recorded at 148, 282, 715, and $1085 \mathrm{~cm}^{-1}$, as shown in Figure 11a,b. Minor shifts of the positions between the analyzed samples and the spectra published in the literature could be due to the natural impurities of the samples $[59,60]$. The studied samples show distinctive peaks around $1595 \mathrm{~cm}^{-1}$ and $1354 \mathrm{~cm}^{-1}$, related to the presence of $G$ and $D$ bands of the amorphous carbon (AM). These bands were recorded in the fluorescent autochthonous micrite, regardless of the texture type (peloidal or aphanitic). The organic G and D bands were not present in the spectra of non-fluorescent allochthonous fractions, see Figure 12a,b.
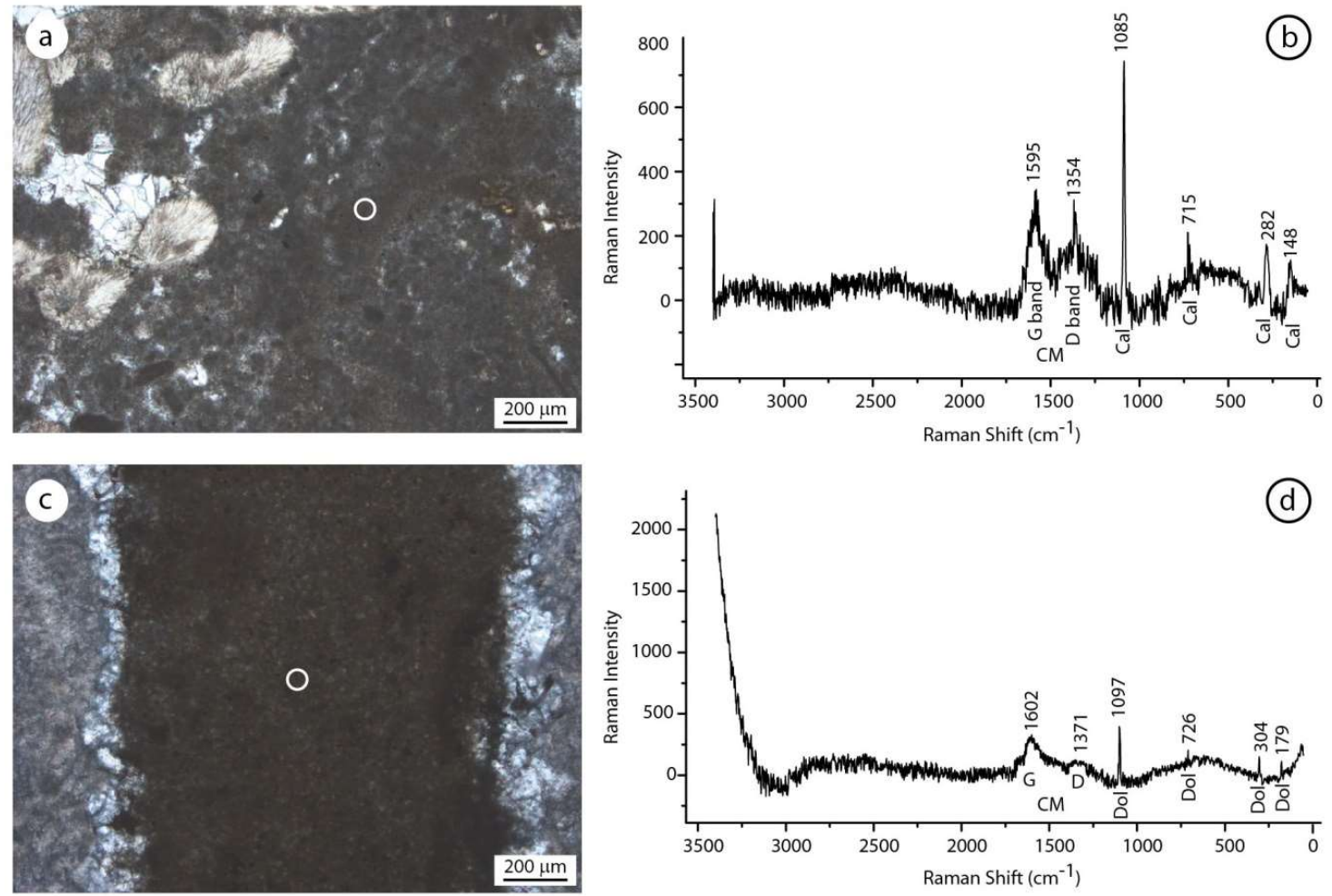

Figure 11. Comparison between the Raman spectra of samples from the erratic boulders of Alpe di Specie and Rifugio Vallandro section. $(\mathbf{a}, \mathbf{b})$ Autochthonous micrite and its Raman spectrum showing the $\mathrm{G}$ and $\mathrm{D}$ bands of the carbonaceous material and the typical calcite (cal) picks. (c,d) Aphanodolomite and its Raman spectrum showing the $G$ band, a very weak D band, and the typical dolomite picks (dol). The carbonaceous material (G and D bands) testify to the presence of carbonaceous material among the aphanodolomite crystals.

The analyses on aphanodolomites of Rifugio Vallandro show the typical dolomite bands. Prominent absorption bands of the dolomite were recorded at 179, 304, 726, and $1097 \mathrm{~cm}^{-1}$, see Figure $11 \mathrm{c}, \mathrm{d}$. Minor shifts of peak positions between the analyzed samples and the published 
literature spectra can be due to the effects of natural impurities or to the presence of non-stoichiometric dolomite. Interestingly, the $\mathrm{G}$ band at $1602 \mathrm{~cm}^{-1}$ is similar to that of the autochthonous micrite of the erratic boulder. The D band around $1335 \mathrm{~cm}^{-1}$ is instead very feeble or not present in the aphanodolomites. The $\mathrm{G}$ and $\mathrm{D}$ bands are not present in finely crystalline dolomite, confirming the absence of carbonaceous material in this component, see Figure 12c,d. In this fraction, the peaks of the dolomite were located at 180, 305, 728, and $1103 \mathrm{~cm}^{-1}$. The Raman spectra of framboidal pyrite show the typical picks at 347,381 , and $434 \mathrm{~cm}^{-1}$, see Figure 13 . The analyses also revealed the presence of carbonaceous material associated with pyrite as testified by the $\mathrm{G}$ band at $1592 \mathrm{~cm}^{-1}$.
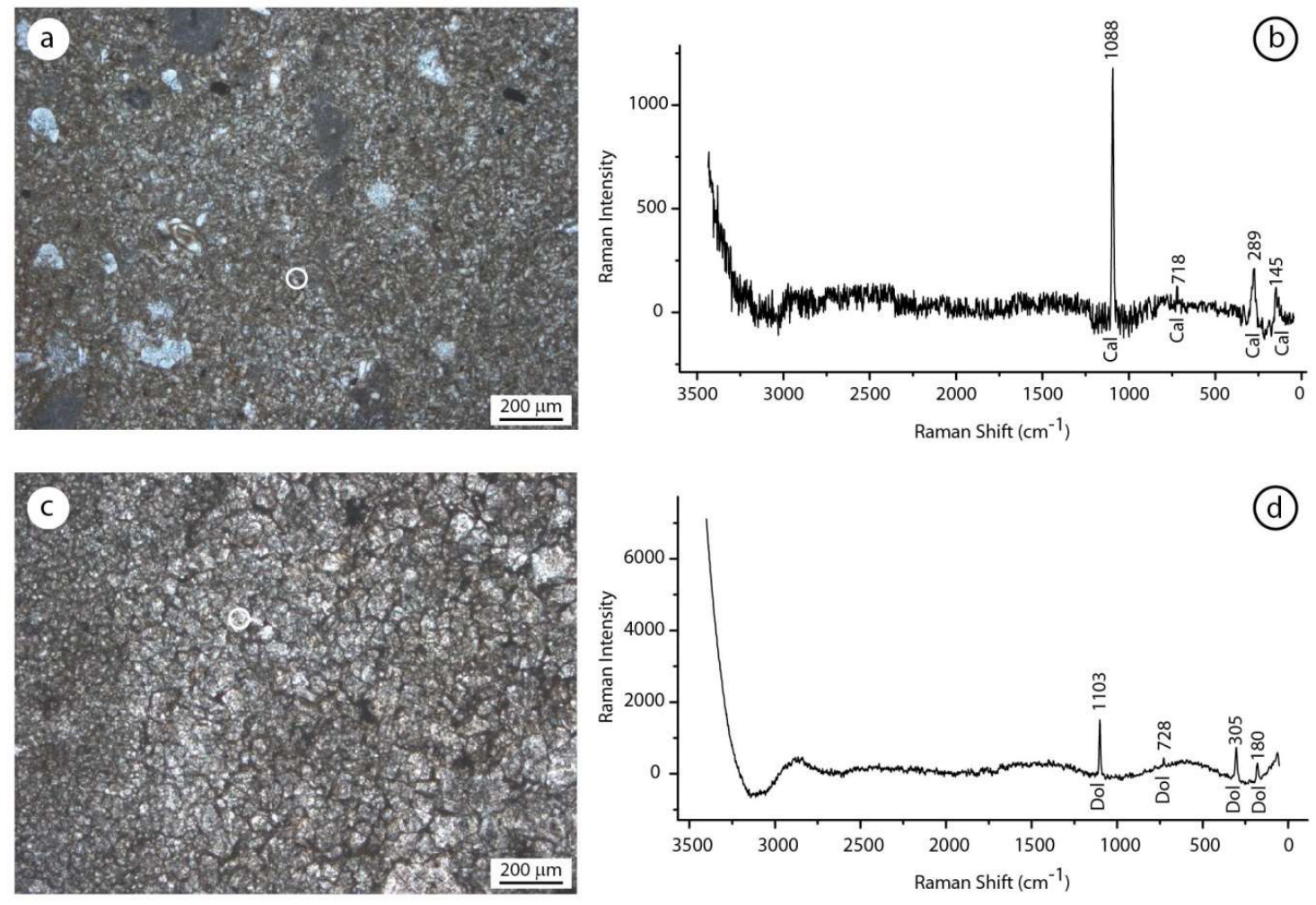

Figure 12. Comparison between the Raman spectra of samples from the erratic boulders of Alpe di Specie and Rifugio Vallandro section. $(\mathbf{a}, \mathbf{b})$ Detrital micrite and relative Raman spectrum showing the typical calcite (cal) picks. (c,d) Finely dolomite crystals and relative Raman spectrum showing the typical dolomite crystals (dol). Note the absence of the carbonaceous material (CM) material in the allochthonous fraction of both the carbonate samples.
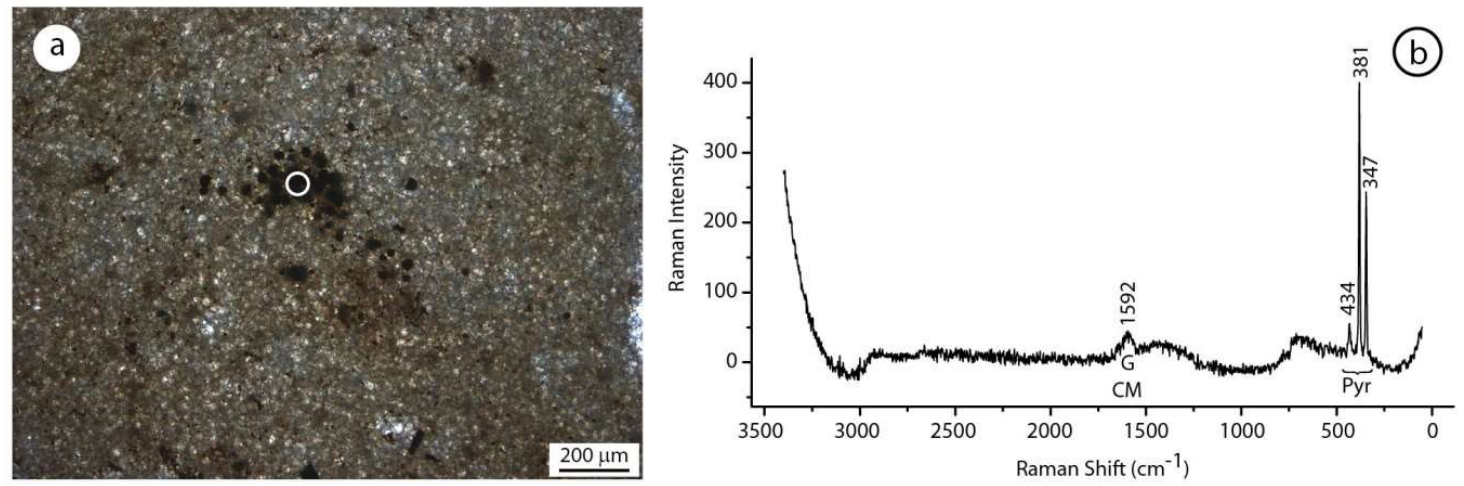

Figure 13. (a) Aphanodolomite with framboidal pyrite. (b) Raman spectrum showing the typical picks of the pyrite. Note the association of the pyrite with graphitized carbonaceous material remain testified by the G band. 


\section{Discussion}

\subsection{The Microbialite in the Erratic Boulders}

Most carbonate platforms in the Dolomites are affected by a pervasive dolomitization that obliterates facies; therefore, the understanding of paleoenvironments and depositional dynamics remains largely incomplete. The few isolated outcrops that preserve original primary mineralogy and micromorphology are particularly valuable for elucidating the carbonate systems as the studied Carnian succession.

The Carnian "erratic boulders" of Alpe di Specie, see Figure 5, show an excellent preservation state, including the original mineralogy of skeletal tissues (aragonite or Mg-calcite) and represent a very important source of knowledge about Upper Triassic reef-building organisms [36]. This is due to the embedding of patch reefs in fine basinal sediments of the San Cassiano Fm., which prevented the dolomitizing fluids from altering the primary mineralogical and biochemical characteristics [36]. The presence in this area of both dolomitized patch reefs (Rifugio Vallandro section), see Figure 4 , and isochronous, preserved, carbonate bodies (Alpe di Specie "erratic boulders"), see Figure 5, allowed for a comparison to be made between the two carbonates and the advancement of a hypothesis on the control of the dolomitization processes according to the type of carbonate precursor, see Figure 8.

The small coralgal patch reefs of Alpe di Specie developed in the relatively muddy low-energy environment, see Figure 2. The primary skeletal framework of these bioconstructions was poor in early cement and the diffused cryptic cavities hosted microbial communities fed by the decaying organic matter [58]. The microbial metabolic activities favored the precipitation of autochthonous micrite (microbialites). Peloidal to clotted peloidal and aphanitic micrite fills most of the intra- and inter-skeletal cavities contributing to the syndepositional cementation and stabilization of these bioconstructions, see Figure 6. These micrite types were commonly associated with anaerobic bacteria thriving in cryptic cavities characterized by suboxic to anoxic conditions [61-69]. Recently, microbial activity, inducing biomineralization processes in modern cryptic environments, was recognized in bioconstructions growing on submarine caves [70-74]. Biomarkers, with a high specificity of sulfate-reducing bacteria, are indicative of a univocal microbial process mediating the precipitation of microbialite in the marine caves $[75,76]$. Similar microbial processes were inferred for the deposition of autochthonous micrite inside the small cavities of the Triassic patch reefs. These coralgal patch reefs contain sulfate reducing bacteria (SRB) biomarkers, lack specific molecules typical of cyanobacteria, and have Rare Earth Elements (REE) values indicative of suboxic conditions [58,77-79].

\subsection{Organic Matter in the Aphanodolomite of Rifugio Vallandro}

Although the Rifugio Vallandro section is dolomitized, its faunal content and facies patterns show strong affinities with those of the erratic boulders, see Figures 7 and 8 . Considering the paleontological content and the geometrical and stratigraphic relationships recognized in the study area, Russo et al. [36] correlated the Rifugio Vallandro beds with the erratic boulders. The peloidal and aphanitic micrite texture of the microbialite is still observable in the dolomitized samples, see Figures 7 and 8 . The dolomite replaces the original calcite with a very small increase (aggrading) of crystal sizes and the neo-formed texture mimes the original fabric, still allowing the identification of the microbialite precursor.

The microbialites, rich in organic matter remains, may have had a role in the dolomitization processes affecting the Rifugio Vallandro carbonates. The organic content of the aphanodolomite is confirmed by its epifluorescence, shown in Figure $7 \mathrm{f}$, which represents the property of the material to emit light when excited by visible or ultraviolet light $[55,80]$. In limestone, fluorescence is due to the presence of organic impurities in the crystalline lattice; however, some mineral species fluoresce due to trace element activation [81]. However, the detection of the carbonaceous material bands in Raman spectra confirm the presence of organic matter in the aphanodolomites. 
The two wavelength intervals at $1100-1800 \mathrm{~cm}^{-1}$ and $2500-3100 \mathrm{~cm}^{-1}$ were referred to as the firstand second-order regions of Raman spectra of organic matter (carbonaceous material, CM) [82-86]. In the first-order region, well-organized graphite has a detectable vibration mode at $1580 \mathrm{~cm}^{-1}$, which is an in-plane mode $[83,84]$. This peak is named " $G$ band" and, in disordered or poorly-organized CM, it splits into two peaks; the $G$ band at around $1600 \mathrm{~cm}^{-1}$ and the $\mathrm{D}$ band at around $1355 \mathrm{~cm}^{-1}$ [86]. The $\mathrm{G}$ band was recorded only in the aphanodolomites, see Figure 11d, whereas it is absent in the finely crystalline dolomite, see Figure $12 \mathrm{~d}$. The presence of the $\mathrm{G}$ band in the aphanodolomites, in the same positions where high epifluorescence was observed, substantiated the presence of organic matter relics. Differently from the autochthonous micrite of an erratic boulder, in the aphanodolomites, the D bands are very feeble or not present, testifying to a greater order degree of the carbonaceous material in the dolomitized samples.

The spectra of aphanodolomites and finely crystalline dolomites display differences in the intensity and resolution of the main peaks. The finely crystalline dolomite shows clearer spectra with well-defined peaks in comparison to the spectra of aphanodolomite that show higher fluorescence phenomena. This behavior could be linked to the carbonaceous material content that seems to influence the Raman scattering in the microbialite.

Traces of organic matter in the aphanodolomite are also confirmed by the amorphous substance, see Figure 10c,d, and the micro-spheroidal corpuscles, see Figure 10c, observed with SEM. The amorphous substance could represent remains of mineralized extracellular polymeric substance (EPS) while micro-spheroidal corpuscles could represent remains of bacterial mineralized bodies.

\subsection{Influence of the Organic Matter in the Dolomitization Process}

The origin of dolomite has been extensively studied and many depositional and geochemical models have been proposed [15-19,21]. An important aspect of dolomite mineralization is how the barriers of dolomite nucleation may be overcome at earth-surface temperature. These barriers appear to be overcome within some anoxic, organic-rich sediments as a result of bacterial sulfate reduction and methanogenesis $[13,14]$. Sulfate reduction and methanogenesis are mediated by bacteria in anoxic, organic-rich sediments, mainly composed of highly reactive, proteinaceous (nitrogen-rich) organic matter. This protein-rich material derives mainly from bacteria, lacustrine and marine algae, and is preserved in either anoxic lakes or carbonate marine environments [87]. Slaughter and Hill [13] proposed that the decomposition of proteinaceous organic debris by sulfate-reducing bacteria has a critical control over organogenic dolomitization. The decomposition of the proteinaceous organic matter produces relatively high concentrations of ammonia $\left(\mathrm{NH}_{3}\right)$ and carbon dioxide $\left(\mathrm{CO}_{2}\right)$. Ammonia controls $\mathrm{pH}$, and, therefore, $\mathrm{CO}_{3}{ }^{-2}$ activity, ion pairing, and carbonate surface chemistry. It raises the $\mathrm{pH}$ of the system either locally or on a larger scale, allowing dolomitization to proceed.

In the Alpe di Specie patch reefs, the skeletal framework is rich in cavities, characterized by suboxic/anoxic conditions, in which the organic matter decay favor bacterial activities. In particular, the organic matter enrichment contributes to feed sulfate-reducing bacteria in these cavities that, in turn, induce autochthonous micrite deposition [58]. This micrite is rich in microbial organic matter and, according to the organodolomitization model proposed by Slaughter and Hill [13] and Mazzullo [14], may have been involved in dolomitization. The Ca-dolomite composition of the poorly ordered aphanodolomites and the absence of Fe are in agreement with the replacive nature of this component. Organogenic dolomites are typically characterized by fine crystals, generally less than $10 \mu \mathrm{m}$, and most are calcic and poorly ordered [14,88-93]. Furthermore, the involvement of sulfate reduction in the organodolomitization of the microbialite from Rifugio Vallandro is testified by the absence of Fe in the aphanodolomites because available Fe was rapidly incorporated into sulfide minerals (pyrite). On the contrary, allochthonous micrite, being poor in organic matter, transforms into larger dolomite crystals (finely crystalline dolomite).

We hypothesize four diagenetic phases for the dolomitization of the Rifugio Vallandro section. In the first phase, it seems that aragonite and Mg-calcite skeletal grains dissolve. In the second phase, 
the enzymatic decaying of the organic matter produced interstitial alkaline environments, favoring the dolomitization of the autochthonous micrite (microbialites). This phase formed very finely dolomite (aphanodolomites) whereas the detrital micrites were not involved in the process. In the third phase, the detrital micrite was replaced by finely crystalline dolomite, while the aphanodolomites slightly aggraded in larger crystals. In the last diagenetic phase, late sparry calcite precipitates in the cavities left by the dissolution of skeletal grains.

Experiments demonstrated the possibility of mineralizing the primary dolomite in the laboratory [2-4] and it was also observed in recent environments [94-96]. In the fossil record, similarly to the recent $\mathrm{Ca}: \mathrm{Mg}$ mineral phases, stromatolitic laminae of dolomite were observed, and they were interpreted as primary phases, precipitated at surface settings [7,12,97,98]. Considering the observation on the studied Carnian samples, that allowed comparison of the pristine Ca-microbialite with isochronous re-mineralized Ca:Mg microbialite, particular attention should be paid to the interpretation of fossil autochthonous carbonates. In fact, organodiagenetic processes can induce the dolomitization of Ca-microbialite, forming a microfabric miming the primary texture.

\section{Conclusions}

The comparison between the Carnian carbonates of the well-preserved "erratic boulders" of Alpe di Specie and the isochronous, recrystallized, and dolomitized erratic boulders of the Rifugio Vallandro section allows the hypothesizing of the role of microbialites on dolomitization processes. Microbialites form in the cryptic cavities of the patch reef through microbial metabolic activity of sulfate-reducing bacteria that thrive on organic matter and are accumulated in the suboxic to anoxic interspaces of the skeletal framework. Microbial extracellular polymeric substance (EPS) and other organic compounds, that remain trapped inside the fine crystals of the peloidal and aphanitic micrite, may have a role in the dolomitization processes of the microbialites. High $\mathrm{pH}$ and high alkalinity, derived by the degradation of the organic matter, may be critical in promoting the dolomitization of microbialites because the high $\mathrm{pH}$ increases the concentration and activity of the dissolved $\mathrm{CO}_{3}{ }^{2-}$, thereby increasing the dolomite supersaturation and reaction rates. This process produces very finely crystalline dolomite (aphanodolomite) that replaces the original organic-rich micrite. The degradation of organic matter suggests an early dolomitization of the microbialite in comparison to the organic matter poor allochthonous micrite that diagenized later, forming larger euhedral dolomite crystals. The research on organodolomitization processes, led through different types of micrites (autochthonous or allochthonous), could help to clarify the dolomitization processes of large carbonate volumes such as the Dolomites, and it suggests particular attention is needed when interpreting some dolomites as primary in the fossil record.

Author Contributions: A.G., F.R. and A.M. collected and interpreted the micromorphological and biogeochemical data. D.M. carried out the micro Raman analyses. A.G., F.R., A.M. and D.M. participated in the discussions and in writing and editing the manuscript. All authors read and approved the final manuscript.

Funding: This research received no external funding.

Acknowledgments: We thank Mariano Davoli, University of Calabria, for technical support during SEM and EPMA data acquisition. We appreciated the suggestions of two anonymous reviewers which contributed to improve the manuscript. This research was financially supported by grants MIUR (ex 60\% 2018 A. Mastandrea, University of Calabria).

Conflicts of Interest: The authors declare that the research was conducted in the absence of any commercial orfinancial relationships that could be construed as a potential conflict of interest.

\section{References}

1. Banerjee, A. Estimation of dolomite formation: Dolomite precipitation and dolomitization. J. Geol. Soc. India 2016, 87, 561-572. [CrossRef]

2. Vasconcelos, C.; McKenzie, J.A.; Warthmann, R.; Bernasconi, S. Calibration of $\delta^{18} \mathrm{O}$ paleothermometer for dolomite precipitated in microbial cultures and natural environments. Geology 2005, 33, 317-320. [CrossRef] 
3. Warthmann, R.; van Lith, Y.; Vasconcelos, C.; McKenzie, J.A.; Karpoff, A.M. Bacterially induced dolomite precipitation in anoxic culture experiments. Geology 2000, 28, 1091-1094. [CrossRef]

4. Vasconcelos, C.; McKenzie, J.A. Microbial mediation of modern dolomite precipitation and diagenesis under anoxic conditions (Lagoa Vermelha, Rio de Janeiro, Brazil). J. Sediment. Res. 1997, 67, 378-390.

5. Sanchez-Roman, M.; Vasconcelos, C.; Schmid, T.; Dittrich, M.; Mckenzie, J.A.; Zenobi, R.; Rivadeneyra, M.A. Aerobic microbial dolomite at the nanometer scale: Implications for the geologic record. Geology 2008, 36, 879-882. [CrossRef]

6. Roberts, J.A.; Bennett, P.C.; Gonzalez, L.A.; Macpheson, G.L.; Milliken, K.L. Microbial precipitation of dolomite in methanogenic groundwater. Geology 2004, 32, 277-280. [CrossRef]

7. Mckenzie, J.A.; Vasconcelos, C. Dolomite Mountains and the origin of the dolomite rock of which they mainly consist: Historical developments and new perspectives. Sedimentology 2009, 56, 205-219. [CrossRef]

8. Wright, D.T. Benthic microbial communities and dolomite formation in marine and lacustrine environments-A new dolomite model. In Marine Authigenesis from Global to Microbial; SEPM Spec. Publ.: Tulsa, OK, USA, 2000; pp. 7-20.

9. García del Cura, M.A.; Calvo, J.P.; Ordóñez, S.; Jones, B.F.; Cañaveras, J.C. Petrographic and geochemical evidence for the formation of primary, bacterially induced lacustrine dolomite: La Roda "white earth" (Pliocene, central Spain). Sedimentology 2001, 48, 897-915. [CrossRef]

10. van Lith, Y.; Vasconcelos, C.; Warthmann, R.; McKenzie, J.A. Sulphate-reducing bacteria induce low-temperature Ca-dolomite and high Mg-calcite formation. Geobiology 2003, 1, 71-79. [CrossRef]

11. Rao, V.P.; Kessarkar, P.M.; Krumbein, W.E.; Krajewski, K.P.; Schneider, R.J. Microbial dolomite crusts from the carbonate platform off western India. Sedimentology 2003, 50, 819-830. [CrossRef]

12. Mastandrea, A.; Perri, E.; Russo, F.; Spadafora, A.; Tucker, M.E. Microbial primary dolomite from a Norian carbonate platform: Northern Calabria, southern Italy. Sedimentology 2006, 53, 465-480. [CrossRef]

13. Slaughter, M.; Hill, R.J. The inuence of organic matter in organogenic dolomitization. J. Sediment. Petrol. 1991, 61, 296-303. [CrossRef]

14. Mazzullo, S.J. Organogenic dolomitization in peritidal to deep-sea sediments. J. Sediment. Res. 2000, 70, 10-23. [CrossRef]

15. Machel, H.G.; Mountjoy, E.W. Chemistry and environments of dolomitization-A reappraisal. Earth Sci. Rev. 1986, 23, 175-222. [CrossRef]

16. Machel, H.G.; Mountjoy, E.W. General constraints on extensive pervasive dolomitization and their application to the Devonian carbonates of Western Canada. Bull. Can. Petrol. Geol. 1987, 35, 143-158.

17. Hardie, L.A. Dolomitization: A critical view of some current views. J. Sediment. Petrol. 1987, 57, $166-183$. [CrossRef]

18. Morrow, D.W. Dolomite-Part 1: The chemistry of dolomitization and dolomite precipitation. Geosci. Can. 1990, 4, 113-123.

19. Morrow, D.W. Dolomite-Part 2: Dolomitization models and ancient dolostones. Geosci. Can. 1990, 4, 125-139.

20. Braithwaite, C.J.R. Dolomites, a review of origins, geometry and textures. Trans. R. Soc. Edinb. 1991, 82, 99-112. [CrossRef]

21. Purser, B.; Tucker, M.; Zenger, D. Dolomites, a Volume in Honour of Dolomieu, 1st ed.; International Association of Sedimentologists, Special Publication; Wiley-Blackwell: Hoboken, NJ, USA, 1994; p. 451.

22. Tucker, M.E. Precambrian dolomites: Petrographic and isotopic evidence that they differ from Phanerozoic dolomites. Geology 1982, 10, 7-12. [CrossRef]

23. Morse, J.W.; Mackenzie, F.T. Geochemistry of Sedimentary Carbonates; Elsevier: Amsterdam, The Netherlands, 1990; p. 707.

24. Tucker, M.E.; Wright, V.P.; Dickson, J.A.D. Carbonate Sedimentology; Blackwell Science Ltd.: Oxford, UK, 2002; p. 482.

25. Machel, H.G. Concepts and models of dolomitization: A critical reappraisal. In The Geometry and Petrogenesis of Dolomite Hydrocarbon Reservoirs; Geological Society: London, UK, 2004; Volume 235, pp. 7-63.

26. Whitaker, F.F.; Xiao, Y. Reactive transport modeling of early burial dolomitization of carbonate platforms by geothermal convection. AAPG Bull. 2004, 94, 889-917. [CrossRef]

27. Al-Helal, A.B.; Whitaker, F.F.; Xiao, Y. Reactive transport modeling of brine reflux: Dolomitization, anhydrite precipitation, and porosity evolution. J. Sediment. Res. 2012, 82, 196-215. [CrossRef] 
28. Merino, E.; Canals, A. Self-accelerating dolomite for calcite replacement: Self organized dynamics of burial dolomitization and associated mineralization. Am. J. Sci. 2011, 311, 573-607. [CrossRef]

29. Compton, J.S. Degree of supersaturation and precipitation of organogenic dolomite. Geology 1988, 16, 318-321. [CrossRef]

30. McKenzie, J.A.; Hsü, K.J.; Schneider, J.F. Movement of Subsurface Waters under the Sabkha, Abu Dhabi, UAE, and Its Relation to Evaporative Dolomite Genesis; SEPM Spec. Publ.: Tulsa, OK, USA, 1980; Volume 28, pp. 11-30.

31. Adams, J.E.; Rhodes, M.L. Dolomitization by seepage refluxion. Am. Assoc. Petrol. Geol. Bull. 1960, 44, 1912-1921.

32. Bosellini, A. La tematica deposizionale della Dolomia Principale. Boll. Soc. Geol. Ital. 1967, 86, 133-169.

33. Reeder, R.J. Electron optical investigation of sedimentary dolomites. Contrib. Mineral. Petrol. 1981, 76, 148-157. [CrossRef]

34. Frisia, S.; Wenk, H.-R. TEM and AEM study of pervasive, multi-step dolomitization of the upper Triassic Dolomia Principale (Northern Italy). J. Sediment. Petrol. 1993, 63, 1049-1058.

35. Wenk, H.-R.; Meisheng, H.; Frisia, S. Partially disordered dolomite: Microstructural characterization of Abu Dhabi sabkha carbonates. Am. Mineral. 1993, 78, 769-774.

36. Russo, F.; Neri, C.; Mastandrea, A.; Laghi, G. Depositional and diagenetic history of the Alpe di Specie (Seelandalpe) fauna (Carnian, northeastern Dolomites). Facies 1991, 25, 187-210. [CrossRef]

37. Stefani, M.; Brack, P.; Gianolla, P.; Keim, L.; Mastandrea, A.; Maurer, F.; Neri, C.; Preto, N.; Ragazzi, E.; Riva, A.; et al. Triassic carbonate platforms of the Dolomites: Carbonate production, relative sea-level fluctuations and the shaping of the depositional architecture. In Field Trip Guidebook, Proceedings of the 32nd International Geological Congress, Florence, Italy, 20-28 August 2004; APAT: Rome, Italy, 2004; pp. 44-64.

38. Stefani, M.; Furin, S.; Gianolla, P. The changing climate framework and depositional dynamics of Triassic carbonate platforms from the Dolomites. Palaeogeogr. Palaeoclimatol. Palaeoecol. 2010, 290, 43-57. [CrossRef]

39. Guido, A.; Mastandrea, A.; Stefani, M.; Russo, F. Role of autochthonous versus detrital micrite in depositional geometries of Middle Triassic carbonate platform systems. Geol. Soc. Am. Bull. 2016, 128, 989-999. [CrossRef]

40. Keim, L.; Brandner, R.; Krystyn, L.; Mette, W. Termination of carbonate slope progradation: An example from the Carnian of the Dolomites, Northern Italy. Sediment. Geol. 2001, 143, 303-323. [CrossRef]

41. Pisa, G.; Farabegoli, E.; Ott, E. Stratigrafia e paleogeografia dei terreni anisici della Conca di Agordo e della Alta Val di Zoldo (Dolomiti sudorientali). Mem. Soc. Geol. Ital. 1978, 18, 63-92.

42. Bosellini, A. Progradation geometries of carbonate platforms: Examples from the Triassic of the Dolomites, northern Italy. Sedimentology 1984, 31, 1-24. [CrossRef]

43. De Zanche, V.; Gianolla, P.; Mietto, P.; Siorpaes, C.; Vail, P.R. Triassic sequence stratigraphy in the Dolomites (Italy). Mem. Sci. Geol. 1993, 45, 1-27.

44. Gianolla, P.; De Zanche, V.; Mietto, P. Triassic sequence stratigraphy in the Southern Alps (northern Italy): Definition of sequences and basin evolution. In Mesozoic-Cenozoic Sequence Stratigraphy of European Basins; SEPM Special Publication: Tulsa, OK, USA, 1998; Volume 60, pp. 719-747.

45. Gianolla, P.; Ragazzi, E.; Roghi, G. Upper Triassic amber from the Dolomites (northern Italy): A paleoclimatic indicator? Riv. Ital. Paleont. Strat. 1998, 104, 381-389.

46. Preto, N.; Hinnov, L.A. Unraveling the origin of carbonate platform cyclothems in the Upper Triassic Durrenstein Formation (Dolomites, Italy). J. Sediment. Res. 2003, 73, 774-789. [CrossRef]

47. Scherer, M. Preservation, alteration and multiple cementation of aragonite skeletons from the Cassian Beds (Upper Triassic, Southern Alps). Petrographic and geochemical evidence. Neues Jahrbuch Geologisch Paläontologisch Abhandlung 1977, 154, 213-262.

48. Senowbari-Daryan, B.; Flügel, E.; Preto, N. Tethysocarnia cautica n. gen. n. sp., a sessile foraminifer from Late Ladinian and Carnian reefs of the western and southern Tethys. Geologica et Paleontologica 2001, 35, 105-119.

49. Bosellini, A.; Gianolla, P.; Stefani, M. Geology of the Dolomites. Episodes 2003, 26, 181-185.

50. Loretz, H. Einige Petrefakten der alpinen Trias aus den Südalpen. Z. Dtsch. Geol. Ges. 1875, 27, $784-841$.

51. Ogilvie, M.M. Contributions to the Geology of the Wengen and St. Cassian Strata in Southern Tyrol. Q. J. Geol. Soc. Lond. 1893, 49, 1-78. [CrossRef]

52. Pia, J. Stratigraphie und Tektonik der Dolomiten von Prags; A. Weger's fb. Hofbuchdruckerei: Wien, Austria, 1983; p. 248. 
53. Dieci, G.; Antonacci, A.; Zardini, R. Le spugne cassiane (Trias medio-superiore) della regione dolomitica attorno a Cortina d'Ampezzo. Bol. Soc. Paleont. Ital. 1970, 7, 94-155.

54. Fürsich, F.T.; Wendt, J. Biostratinomy and palaeoecology of the Cassian Formation (Triassic) of the Southern Alps. Palaeogeogr. Palaeoclimatol. Palaeoecol. 1977, 22, 257-323. [CrossRef]

55. Neuweiler, F.; Reitner, J. Epifluorescence microscopy of selected automicrites from lower Carnian Cipit boulders of the Cassian formation (Seeland Alpe, Dolomites). Facies 1995, 32, 26-28.

56. Sánchez-Beristain, J.F.; Schäfer, N.; Simon, K.; Reitner, J. New geochemical method to characterise microbialites from the St. Cassian Formation, Dolomites, Northeastern Italy. In Advances in Stromatolite Geobiology; Springer: Berlin/Heidelberg, Germany, 2011; Volume 131, pp. 435-451.

57. Wendt, J. The Cassian patch reefs (Lower Carnian, Southern Alps). Facies 1982, 6, 185-202. [CrossRef]

58. Tosti, F.; Mastandrea, A.; Guido, A.; Demasi, F.; Russo, F.; Riding, R. Biogeochemical and redox record of mid-Late Triassic reef evolution in the Italian Dolomites. Palaeogeogr. Palaeoclimatol. Palaeoecol. 2014, 399, 52-66. [CrossRef]

59. Buzgar, N.; Apopei, A.I. The Raman study of certain carbonates. Geologie Tomul L 2009, 2, $98-112$.

60. Miriello, D.; Bloise, A.; Crisci, G.M.; De Luca, R.; De Nigris, B.; Martellone, A.; Osanna, M.; Pace, R.; Pecci, A.; Ruggieri, N. Non-destructive multi-analytical approach to study the pigments of wall painting fragments reused in mortars from the archaeological site of Pompeii (Italy). Minerals 2018, 8, 134. [CrossRef]

61. Monty, C.L.V. The origin and development of cryptalgal fabrics. In Stromatolites. Developments in Sedimentology; Springer: Amsterdam, The Netherland, 1976; pp. 193-249.

62. Chafetz, H.S. Marine peloids: A product of bacterially induced precipitation of calcite. J. Sediment. Petrol. 1986, 56, 812-817.

63. Buczynski, C.; Chafetz, H.S. Habit of bacterially induced precipitates of calcium carbonate and the influence ofmedium viscosity on mineralogy. J. Sediment. Petrol. 1991, 61, 226-233. [CrossRef]

64. Reitner, J. Modern cryptic microbialite/metazoan facies from LizardBarrier Reef, Australia): Formation and concepts. Facies 1993, 29, 3-40. [CrossRef]

65. Kazmierczak, J.; Coleman, M.L.; Gruszczynski, M.; Kempe, S. Cyanobacterial key to the genesis of micritic and peloidal limestones in ancient seas. Acta Palaeontol. Pol. 1996, 41, 319-338.

66. Folk, R.L.; Chafetz, H.S. Bacterially induced microscale and nanoscale carbonate precipitates. In Microbial Sediments; Springer-Verlag: Berlin, Germany, 2000; pp. 40-49.

67. Riding, R. Structure and composition of organic reefs and carbonate mud mounds: Concepts and categories. Earth Sci. Rev. 2002, 58, 163-231. [CrossRef]

68. Riding, R.; Tomás, S. Stromatolite reef crusts, Early Cretaceous, Spain: Bacterial origin of in situ precipitated peloid microspar? Sedimentology 2006, 53, 23-34. [CrossRef]

69. Guido, A.; Jimenez, C.; Achilleos, K.; Rosso, A.; Sanfilippo, R.; Hadjioannou, L.; Russo, F.; Mastandrea, A. Geomicrobiology of the Kakoskali submarine cave (Cyprus, eastern Mediterranean). Facies 2017, 63, 21. [CrossRef]

70. Guido, A.; Mastandrea, A.; Rosso, A.; Sanfilippo, R.; Russo, F. Micrite precipitation induced by sulphate reducing bacteria in serpulid bioconstructions from submarine caves (Syracuse, Sicily). Rend. Online Soc. Geol. Ital. 2012, 21, 933-934.

71. Guido, A.; Mastandrea, A.; Rosso, A.; Sanfilippo, R.; Tosti, F.; Riding, R.; Russo, F. Commensal symbiosis between agglutinated polychaetes and sulfate reducing bacteria. Geobiology 2014, 12, 265-275. [CrossRef]

72. Guido, A.; Rosso, A.; Sanfilippo, R.; Russo, F.; Mastandrea, A. Frutexites from microbial/metazoan bioconstructions of recent and Pleistocene marine caves (Sicily, Italy). Palaeogeogr. Palaeoclimatol. Palaeoecol. 2016, 453, 127-138. [CrossRef]

73. Guido, A.; Rosso, A.; Sanfilippo, R.; Russo, F.; Mastandrea, A. Microbial biomineralization in biotic crusts from a Pleistocene marine cave (NW Sicily, Italy). Geomicrobiol. J. 2017, 34, 864-872. [CrossRef]

74. Sanfilippo, R.; Rosso, A.; Guido, A.; Mastandrea, A.; Russo, F.; Riding, R.; Ruggiero, E.T. Metazoan/microbial biostalactites from present-day submarine caves in the Mediterranean Sea. Mar. Ecol. 2015, 36, 1277-1293. [CrossRef]

75. Gischler, E.; Heindel, K.; Birgel, D.; Brunner, B.; Reitner, J.; Peckmann, J. Cryptic biostalactites in a submerged karst cave of the Belize Barrier Reef revisited: Pendant bioconstructions cemented by microbial micrite. Palaeogeogr. Palaeoclimatol. Palaeoecol. 2017, 278, 34-51. [CrossRef] 
76. Guido, A.; Heindel, K.; Birgel, D.; Rosso, A.; Mastandrea, A.; Sanfilippo, R.; Russo, F.; Peckmann, J. Pendant bioconstructions cemented by microbial carbonate in submerged marine caves (Holocene, SE Sicily). Palaeogeogr. Palaeoclimatol. Palaeoecol. 2013, 388, 166-180. [CrossRef]

77. Tosti, F.; Guido, A.; Demasi, F.; Mastandrea, A.; Naccarato, A.; Tagarelli, A.; Russo, F. Microbialites as primary builders of the Ladinian-Carnian platforms in the Dolomites: Biogeochemical characterization. Geo Alp. 2011, 8, 156-162.

78. Tosti, F.; Guido, A.; Demasi, F.; Mastandrea, A.; Russo, F. Biogeochemical characterization of automicrites building the Cipit Boulders of the Ladinian-Carnian platforms in the Dolomites (northeastern Italy). Rend. Online Soc. Geol. Ital. 2011, 17, 179-183.

79. Tosti, F.; Guido, A.; Mastandrea, A.; Demasi, F.; Russo, F. Rare earth elements signature in Triassic samples from Punta Grohmann and Alpe di Specie (Dolomites, Italy): Evidence of cyanobacterial vs sulfate reducing bacteria metabolic activities. Rend. Online Soc. Geol. Ital. 2012, 21, 943-944.

80. Russo, F.; Neri, C.; Mastandrea, A.; Baracca, A. The mud-mound nature of the Cassian platform margins of the Dolomites. A case history: The Cipit boulders from Punta Grohmann (Sasso Piatto Massif, northern Italy). Facies 1997, 36, 25-36. [CrossRef]

81. Van Gijzel, P. Manual of the technique and some geological applications of fluorescence microscopy. In Proceedings of American Association of Stratigraphers and Palynologists Workshop, Dallas, TX, USA, 29 October-2 November 1979; AASP Foundation: Dallas, TX, USA, 1979; p. 55.

82. Beyssac, O.; Goffé, B.; Petitet, J.-P.; Froigneux, E.; Moreau, M.; Rouzaud, J.-N. On the characterization of disordered and heterogeneous carbonaceous materials by Raman spectroscopy. Spectrochim. Acta Part A Mol. Biomol. Spectrosc. 2003, 59, 2267-2276. [CrossRef]

83. Pasteris, J.D.; Wopenka, B. Necessary, but Not Sufficient: Raman Identification of Disordered Carbon as a Signature of Ancient Life. Astrobiology 2003, 3, 727-738. [CrossRef]

84. Wopenka, B.; Pasteris, J.D.P. Structural characterization of kerogens to granulite-facies graphite: Applicability of Raman microprobe spectroscopy. Am. Mineral. 1993, 78, 533-557.

85. Yui, T.F.; Huang, E.; Xu, J. Raman spectrum of carbonaceous material: A possible metamorphic 453 grade indicator for low-grade metamorphic rocks. J. Metamorph. Geol. 1996, 14, 115-124. [CrossRef]

86. Hu, S.; Evans, K.; Crawc, D.; Rempel, K.; Bourdet, J.; Dick, J.; Grice, K. Raman characterization of carbonaceous material in the Macraes orogenic gold deposit and metasedimentary host rocks, New Zealand. Ore Geol. Rev. 2015, 70, 80-95. [CrossRef]

87. Huc, A.Y. Origin and formation of organic matter in recent sediments and its relationship to kerogen. In Kerogen; Editions Technip: Paris, France, 1980; p. 474.

88. Kelts, K.; Mckenzie, J.A. Diagenetic dolomite formation in Quaternary anoxic diatomaceous muds of DSDP Leg 64, Gulf of California. In Initial Reports of the Deep Sea Drilling Project; U.S. Government Printing Office: Washington, DC, USA, 1982; Volume 64, pp. 553-569.

89. Gunatilaka, A.; Saleh, A.; Al-Temeemi, A.; Nassar, N. Occurrence of subtidal dolomite in a shallow hypersaline lagoon, Kuwait. Nature 1984, 311, 450-452. [CrossRef]

90. Lyons, W.B.; Long, D.T.; Hines, M.E.; Gaudette, H.E.; Armstrong, P.B. Calcification of cyanobacterial mats in Solar Lake, Sinai. Geology 1984, 12, 623-626. [CrossRef]

91. Mazzullo, S.J.; Reid, A.M.; Gregg, J.M. Dolomitization of Holocene Mg-calcite supratidal deposits, Ambergris Cay, Belize. Geol. Soc. Am. Bull. 1987, 98, 224-231. [CrossRef]

92. Suess, E.; Von Huene, R. Ocean Drilling Program Leg 112, Peru continental margin: Part 2, sedimentary history and diagenesis in a coastal upwelling environment. Geology 1988, 16, 939-943. [CrossRef]

93. Whitaker, F.F.; Smart, P.L.; Vahrenkamp, V.C.; Nicholson, H.; Wogelius, R.A. Dolomitization by near-normal seawater? Field evidence from the Bahamas. In Dolomites, A Volume in Honour of Dolomieu, 1st ed.; International Association of Sedimentologists, Special Publication; Wiley-Blackwell: Hoboken, NJ, USA, 1994; Volume 21, pp. 111-132.

94. Vasconcelos, C.; Mckenzie, J.A.; Bernasconi, S.; Grujic, D.; Tien, A.J. Microbial mediation as a possible mechanism for dolomite formation. Nature 1995, 377, 220-222. [CrossRef]

95. Bontognali, T.; Vasconcelos, C.; Warthmann, R.J.; Bernasconi, S.; Dupraz, C.; Strohmenger, C.J.; Mckenzie, J.A. Dolomite formation within microbial mats in the coastal sabkha of Abu Dhabi (United Arab Emirates). Sedimentology 2010, 57, 824-844. [CrossRef] 
96. Spadafora, A.; Perri, E.; Mckenzie, J.A.; Vasconcelos, C. Microbial biomineralization processes forming modern Ca:Mg carbonate stromatolites. Sedimentology 2010, 57, 27-40. [CrossRef]

97. Perri, E.; Tucker, M.E.; Mawson, M. Biotic and abiotic processes in the formation and diagenesis of Permian dolomitic stromatolites (Zechstein Group, NE England). J. Sediment. Res. 2013, 83, 896-914. [CrossRef]

98. Preto, N.; Breda, A.; Corso, J.D.; Spotl, C.; Zorzi, F.; Frisia, S. Primary dolomite in the Late Triassic Travenanzes Formation, dolomites, Northern Italy: Facies control and possible bacterial influence. Sedimentology 2014, 62, 697-716. [CrossRef]

(C) 2018 by the authors. Licensee MDPI, Basel, Switzerland. This article is an open access article distributed under the terms and conditions of the Creative Commons Attribution (CC BY) license (http://creativecommons.org/licenses/by/4.0/). 